\title{
Comprehensive Interpretation of the Laboratory Experiments Results to Construct Model of the Polish Shale Gas Rocks
}

\author{
Jadwiga A. Jarzyna ${ }^{1, *}$, Paulina I. Krakowska ${ }^{1}$, Edyta Puskarczyk $^{1}$, \\ Kamila Wawrzyniak-Guz ${ }^{1}$, and Marcin Zych ${ }^{1}$ \\ ${ }^{1}$ AGH University of Science and Technology, Faculty of Geology Geophysics and Environmental \\ Protection, A. Mickiewicza Av. 30, 30-059 Krakow, Poland
}

\begin{abstract}
More than 70 rock samples from so-called sweet spots, i.e. the Ordovician Sa Formation and Silurian Ja Member of Pa Formation from the Baltic Basin (North Poland) were examined in the laboratory to determine bulk and grain density, total and effective/dynamic porosity, absolute permeability, pore diameters size, total surface area, and natural radioactivity. Results of the pyrolysis, i.e., TOC (Total Organic Carbon) together with S1 and $\mathrm{S} 2$ - parameters used to determine the hydrocarbon generation potential of rocks, were also considered. Elemental composition from chemical analyses and mineral composition from XRD measurements were also included. SCAL analysis, NMR experiments, Pressure Decay Permeability measurements together with water immersion porosimetry and adsorption/ desorption of nitrogen vapors method were carried out along with the comprehensive interpretation of the outcomes. Simple and multiple linear statistical regressions were used to recognize mutual relationships between parameters. Observed correlations and in some cases big dispersion of data and discrepancies in the property values obtained from different methods were the basis for building shale gas rock model for well logging interpretation. The model was verified by the result of the Monte Carlo modelling of spectral neutron-gamma log response in comparison with GEM log results. Key words - shale gas rock, porosity, density, TOC, mineral composition.
\end{abstract}

\section{Introduction}

Shale gas deposits belong to the unconventional hydrocarbon (HC) resources. They played important role in the energy balance all over the world since the prices of oil and gas from conventional deposits started enormously increase. They will be still important because conventional HC resources are now deeper and deeper, more difficult and complicated in the aspect of porosity/permeability and saturation determination. Therefore, world companies elaborate the technology of effective shale gas deposits exploitation. Poland belongs to the countries rich in shale gas formations. The most prospective are the Silurian and Ordovician shaly formations located in three Polish sedimentary basins: Baltic, Podlasie, and Lublin in

* Corresponding author: jarzyna@agh.edu.pl 
the north-east and central-east parts of Poland [1, 2]. Polish shale gas formations differ from the most known in literature American Barnett, or other shale plays because of deeper depth of present deposition, different mineral composition, and changeable TOC values [3-5]. Results presented in the paper are typical for the Silurian and Ordovician sweet spots in the Baltic Basin.

\section{Materials and methods}

Laboratory experiments were done on 72 rock plugs cut from the Silurian and Ordovician cores drilled in three on-shore boreholes in the Baltic Basin. Depth intervals, stratigraphic and lithological characteristics of the geological material are presented in Table 1. Depth intervals were similar in BH-2 and BH-3 wells. Samples from BH-1 well were sited deeper. Sequence of the Palaeozoic formations drilled in three boreholes in the study was as follows (going down): Silurian (Llandovery), claystone/mudstone Pa Formation with Ja Member built of bituminous claystone at the bottom, next - Ordovician (Ashgillian) marl, limestone and claystone/mudstone Pr Formation and at the end of the studied intervals - Ordovician (Caradocian/Llanvirnian) bituminous claystone and claystone/mudstone Sa Formation.

Table 1. Rock material for laboratory measurements

\begin{tabular}{|c|c|c|c|c|c|}
\hline \multirow{2}{*}{$\begin{array}{c}\text { Well } \\
\text { (Total no. } \\
\text { of samples) }\end{array}$} & \multirow{2}{*}{$\begin{array}{c}\text { Depth } \\
\text { interval, } \\
{[\mathrm{m}]}\end{array}$} & \multicolumn{2}{|c|}{$\begin{array}{c}\text { Silurian } \\
\text { (Llandovery) }\end{array}$} & \multicolumn{2}{|c|}{$\begin{array}{c}\text { Ordovician } \\
\text { (Carad./ Llanvirn.) }\end{array}$} \\
\hline & & No. of samp. & Lithology & No. of samp. & Lithology \\
\hline \multirow{4}{*}{$\begin{array}{l}\text { BH-1 } \\
(27)\end{array}$} & \multirow{4}{*}{$\begin{array}{c}3185.89- \\
3234.42\end{array}$} & \multirow{4}{*}{5} & \multirow{4}{*}{$\begin{array}{l}\text { claystone/ } \\
\text { mudstone }\end{array}$} & 16 & clay/mudst. \\
\hline & & & & 1 & limestone \\
\hline & & & & 1 & sandstone \\
\hline & & & & 4 & tuff \\
\hline \multirow{3}{*}{$\begin{array}{l}\text { BH-2 } \\
(27)\end{array}$} & \multirow{3}{*}{$\begin{array}{l}2896.38- \\
2938.96\end{array}$} & \multirow{3}{*}{6} & \multirow{3}{*}{$\begin{array}{l}\text { claystone/ } \\
\text { mudstone }\end{array}$} & 17 & clay/mudst. \\
\hline & & & & 1 & limestone \\
\hline & & & & 3 & tuff \\
\hline \multirow{3}{*}{$\begin{array}{c}\text { BH-3 } \\
(18)\end{array}$} & \multirow{3}{*}{$\begin{array}{c}2870.36- \\
2908.76\end{array}$} & \multirow{3}{*}{7} & \multirow{3}{*}{$\begin{array}{l}\text { claystone/ } \\
\text { mudstone }\end{array}$} & 7 & clay/mudst. \\
\hline & & & & 1 & limestone \\
\hline & & & & 3 & tuff \\
\hline
\end{tabular}

\subsection{Rock characteristics}

Majority of the investigated rock samples were claystones/mudstones from two sweet spots: Silurian Ja Member (15 samples) and Ordovician Sa Formation (45 samples). Basic statistics of the selected petrophysical properties of these two shale gas rocks are presented in Table 2. Symbols used in Table 2 are explained in paragraph 2.2 .

\subsection{Laboratory investigations of rock samples}

Mercury injection porosimetry (MIP) was done using AutoPore IV 9500 Micromeritics Co and following parameters were determined: bulk density (at $36.17 \mathrm{psi}$ ), $\rho b[\mathrm{~g} / \mathrm{mL}]$, apparent (skeletal) density, $\rho \mathrm{s}[\mathrm{g} / \mathrm{mL}]$, effective porosity, $\Phi_{\text {eff, }}$ total pore area, TPA $\left[\mathrm{m}^{2} / \mathrm{g}\right]$, average pore diameter, APD $[\mu \mathrm{m}]$, and permeability, K $[\mathrm{mD}]$. Density was also determined with the use of He pycnometer AccuPyc 1330, $\mathrm{\rho He}[\mathrm{g} / \mathrm{ccm}]$. 
Table 2. Basic statistics of the selected petrophysical properties: the Ja Member and Sa Formation; symbols: Min - minimum, Max - maximum, Avg - average, Me - median

\begin{tabular}{|c|c|c|c|c|c|c|c|c|c|}
\hline \multirow{2}{*}{$\begin{array}{l}\text { Type of } \\
\text { measure. }\end{array}$} & \multirow{2}{*}{$\begin{array}{c}\text { Parameter } \\
\text { Stratigraphy }\end{array}$} & Min & $\operatorname{Max}$ & Avg & Me & Min & Max & Avg & Me \\
\hline & & \multicolumn{4}{|c|}{ Silurian Ja Member } & \multicolumn{4}{|c|}{ Ordovician Sa Formation } \\
\hline MIP & $\rho b[\mathrm{~g} / \mathrm{ccm}]$ & 2.28 & 2.54 & 2.42 & 2.37 & 2.23 & 2.97 & 2.43 & 2.51 \\
\hline MIP & $\rho s[\mathrm{~g} / \mathrm{ccm}]$ & 2.35 & 2.57 & 2.36 & 2.44 & 2.29 & 2.98 & 2.49 & 2.55 \\
\hline He pycn. & $\rho \mathrm{He}[\mathrm{g} / \mathrm{ccm}]$ & 2.55 & 2.72 & 2.63 & 2.66 & 2.56 & 3.07 & 2.68 & 2.73 \\
\hline WIP & $\mathrm{GD}_{\text {WIP }}[\mathrm{g} / \mathrm{ccm}]$ & 2.50 & 2.75 & 2.62 & 2.60 & 2.46 & 2.79 & 2.66 & 2.73 \\
\hline MIP & $\Phi_{\text {eff }}[\%]$ & 0.93 & 3.08 & 1.70 & 2.77 & 0.29 & 7.51 & 2.32 & 1.67 \\
\hline NMR & $\Phi_{\mathrm{NMR}_{t} \mathrm{t}}[\%]$ & 0.61 & 1.90 & 1.10 & 1.06 & 0.08 & 5.96 & 2.00 & 0.83 \\
\hline NMR & $\Phi_{\text {NMR_eff }}[\%]$ & 0.10 & 0.38 & 0.20 & 0.24 & 0.01 & 0.73 & 0.29 & 0.18 \\
\hline NMR & $\mathrm{S}_{\mathrm{w}, \text { irr }}[\%]$ & 0.66 & 0.90 & 0.81 & 0.75 & 0.16 & 1.00 & 0.79 & 0.80 \\
\hline NMR & CBW [\%] & 0.49 & 3.31 & 1.48 & 1.60 & 0.15 & 3.51 & 1.62 & 2.72 \\
\hline WIP & $\Phi_{\text {WIP }}[\%]$ & 2.93 & 11.94 & 6.11 & 6.05 & 0.83 & 10.09 & 5.50 & 7.04 \\
\hline DLP & $\Phi_{\text {DLP }}[\%]$ & 2.31 & 9.65 & 4.98 & 3.87 & 0.76 & 7.69 & 4.58 & 5.63 \\
\hline XRD & $\mathrm{OM}[\mathrm{wt} \%]$ & 0.40 & 7.90 & 3.87 & 3.65 & 0.00 & 4.90 & 1.44 & 0.85 \\
\hline \multirow[t]{2}{*}{$\mathrm{NaI}(\mathrm{Tl})$} & $\mathrm{U}[\mathrm{ppm}]$ & 3.24 & 18.64 & 8.17 & 8.65 & 2.03 & 9.80 & 5.13 & 3.89 \\
\hline & Th [ppm] & 8.90 & 12.64 & 11.87 & 12.08 & 4.72 & 26.20 & 11.70 & 10.51 \\
\hline \multirow{3}{*}{$\begin{array}{l}\text { Rock- } \\
\text { Eval }\end{array}$} & TOC [wt $\%]$ & 0.36 & 7.15 & 3.42 & 3.22 & 0.01 & 4.31 & 1.26 & 0.71 \\
\hline & $\mathrm{S} 1$ [mgHC/g r-k] & 0.25 & 2.73 & 1.56 & 1.62 & 0.02 & 3.63 & 0.81 & 0.33 \\
\hline & $\mathrm{S} 2[\mathrm{mgHC} / \mathrm{g} \mathrm{r}-\mathrm{k}]$ & 0.30 & 10.19 & 4.68 & 3.60 & 0.01 & 0.34 & 0.09 & 0.08 \\
\hline MIP & $\mathrm{TPA}\left[\mathrm{m}^{2} / \mathrm{g}\right]$ & 0.41 & 6.52 & 3.22 & 6.02 & 0.11 & 15.25 & 4.83 & 3.44 \\
\hline $\mathrm{N} 2 \mathrm{~A} / \mathrm{D}$ & $\mathrm{S}_{\text {BET }}\left[\mathrm{m}^{2} / \mathrm{g}\right]$ & 2.90 & 10.30 & 6.79 & 6.55 & 0.70 & 40.10 & 13.94 & 13.20 \\
\hline $\mathrm{N} 2 \mathrm{~A} / \mathrm{D}$ & TPV $[\mathrm{ccm} / \mathrm{g}]$ & 0.016 & 0.034 & 0.023 & 0.024 & 0.01 & 0.05 & 0.03 & 0.03 \\
\hline $\mathrm{N} 2 \mathrm{~A} / \mathrm{D}$ & Vmicro $[\mathrm{ccm} / \mathrm{g}]$ & 0.001 & 0.002 & 0.001 & 0.001 & 0.001 & 0.008 & 0.003 & 0.002 \\
\hline N2 A/D & Vmezzo $[\mathrm{ccm} / \mathrm{g}]$ & 0.006 & 0.018 & 0.011 & 0.011 & 0.002 & 0.035 & 0.017 & 0.016 \\
\hline
\end{tabular}

Nuclear Magnetic Resonance (NMR) experiments were done using the Maran Ultra 23 $\mathrm{MHz}$ spectrometer of Resonance Instruments, Ltd and provided total and effective porosity, $\Phi_{\text {NMR_t }}$ and $\Phi_{\text {NMR_eff, }}$ respectively; irreducible water volume, $S_{w, i r r}$, and clay bound water, CBW. Specific method - Dual-Liquid Porosimetry (DLP)/Water Immersion Porosimetry (WIP) $[6,7]$ was used to determine total porosity, $\Phi_{\mathrm{WIP}}[\%]$ and dual liquid porosity, $\Phi_{\mathrm{DLP}}[\%]$, corrected for swelling of water filled samples, together with grain density $G_{\text {WIP }}[\mathrm{g} / \mathrm{ccm}]$. Quantachrome Autosorb-1C automatic gas adsorption apparatus was applied to measure physical adsorption/desorption of nitrogen $\left(\mathrm{N}_{2} \mathrm{~A} / \mathrm{D}\right)$ at $77 \mathrm{~K}$. Nitrogen adsorption/desorption isotherms were used to characterize the specific surface area, $\mathrm{S}_{\mathrm{BET}}\left[\mathrm{m}^{2} / \mathrm{g}\right]$ and pore size (diameters $<350 \mathrm{~nm}$ ) distribution $[8,9]$. The Brunauer - Emmet - Teller (BET), Barrett Joyner - Halenda (BJH) approach, as well as Quenched Solid Density Functional Theory (QSDFT) were adopted for interpretation of adsorption data. From the nitrogen adsorption/ desorption measurements total pore volume (pore diameter less than $350 \mathrm{~nm}$ ), TPV [ccm/g] was calculated and QSDF theory provided with volume of micropores of diameters less than $2 \mathrm{~nm}$, Vmicro [ccm/g] and mezzo pores of diameters 2-50 nm, Vmezzo [ccm/g]. RockEval 6.0 pyrolysis as the organic geochemical analysis oriented to hydrocarbon deposits recognition allowed determination among others of total organic carbon, TOC, free hydrocarbons, S1 and hydrocarbons generated through thermal cracking (residual hydrocarbons, S2) [10]. These parameters are good indicators of rocks rich in organic matter (OM). TOC is well correlated with individual S1 and S2 parameters and also with the sum of them thus, 
each parameter may be used interchangeably for characterization of source rocks. Uranium and thorium contents, $\mathrm{U}$ [ppm] and Th [ppm] measured using apparatus with crystal $\mathrm{NaI}(\mathrm{Tl})$ SKW IUO4 (TESLA) inform on the level of organic matter OM [wt \%] and shale volume VCL [wt \%], respectively, on the basis of natural radioactivity. Values presented in Table 2 and relationships illustrated in chapter 3 present the typical characteristics of the sweet spots of considered shale gas formations, which are an input data to construct rock model.

\section{Relationships between parameters}

Correlations in Figures 1 and 2 illustrate selected examples of mutual relationships between properties comprising various types of porosity, density, and volume of organic matter. They are presented separately for Ja Member and Sa Formation to underline the differences in the bituminous claystone/mudstones building sweet spots. The goal of the presentation of these simple correlations is to show the relationships as an introduction to multidimensional regression and revealed by mutual connections that gas is placed in the bituminous claystone/ mudstone formation in the pore space and also is connected to organic matter. Correlation between the total volume of pores with a diameter less than $350 \mathrm{~nm}$, TPV, and effective

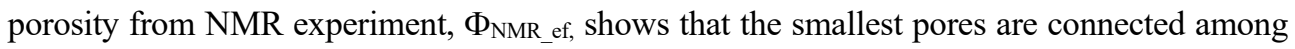
themselves and gas inside can be removed. The relationship between bulk density $\mathrm{pb}$ from MIP and organic matter content calculated together with mineral composition (Fig. 1b) documents distinct density decreasing with organic matter increase and confirms the high importance of density determination. Dispersion observed in plots is caused by heterogeneity of bituminous claystone/mudstones [11, 12].

A good correlation is observed between organic matter content calculated together with the mineral composition on the basis of elements recognition by chemical analysis followed by mineralogical interpretation and TOC from Rock-Eval geochemical measurement (Fig. 1c) despite of different methods of determination. Also, the significant relation is visible in Figure 1d between grain density, determined from water immersed porosity method [7], and TOC. The relationship in Figure 1d confirmed the necessity of precise density measurements and understanding the difference between bulk, skeletal (from MIP) and grain density from WIP method in shale gas rocks. Similar relationships are shown for Sa Formation (Fig. 2a, b). The main feature of these plots in comparison to previous ones is larger number of data but also higher dispersion of points due to geological features of rocks $[11,12]$. Two data sets are distinctly visible in Figure 2a. The first one is more dispersed, marked by oval, and the second one, more consistent. shows TPV porosity increase with the OM decrease. These two sets of data mean that organic matter and small diameter porosity exist alongside in the bituminous claystone/mudstone.

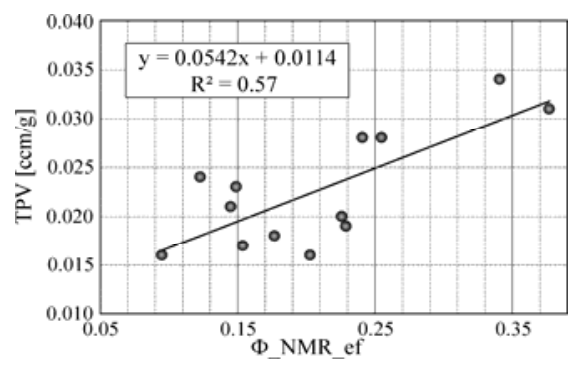

Fig. 1a. Relationship between the total volume of pores less than $350 \mathrm{~nm}$ vs. effective porosity from NMR laboratory experiment, Ja Member

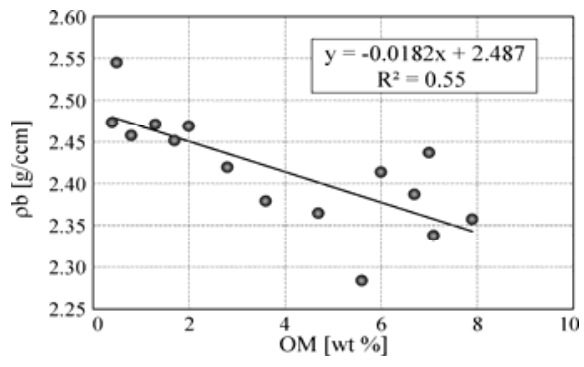

Fig. 1b. Relationship between bulk density from mercury injection porosimetry (MIP) vs. organic matter content, Ja Member 


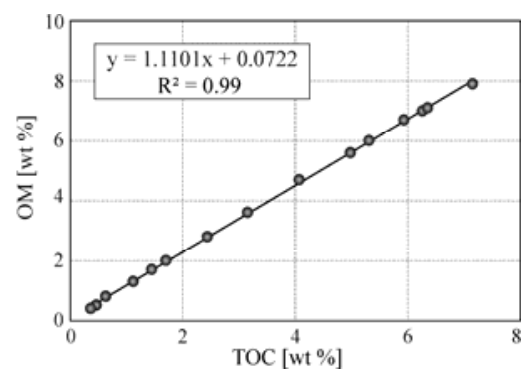

Fig. 1c. Relationship between organic matter content vs. Total Organic Carbon, Ja Member

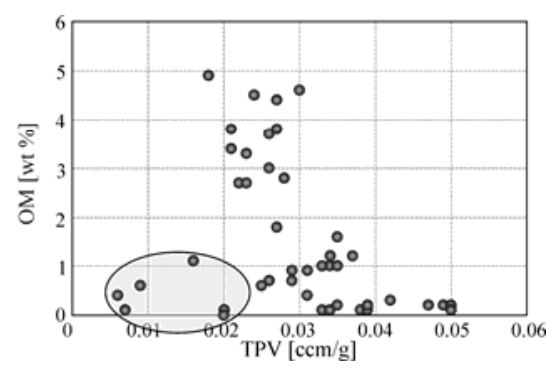

Fig. 2a. Relationship between organic matter content and total porosity including pores $<350 \mathrm{~nm}$, Sa Formation

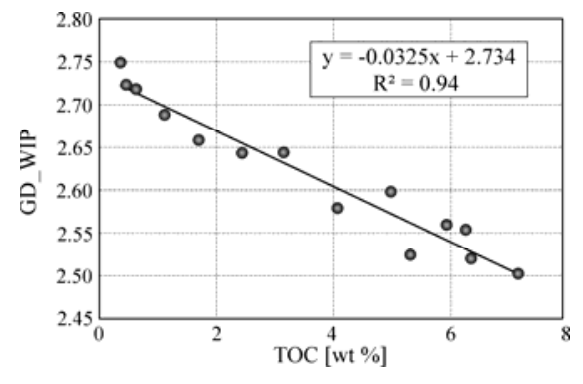

Fig. 1d. Relationship between grain density from WIP method vs. Total Organic Carbon, Ja Member

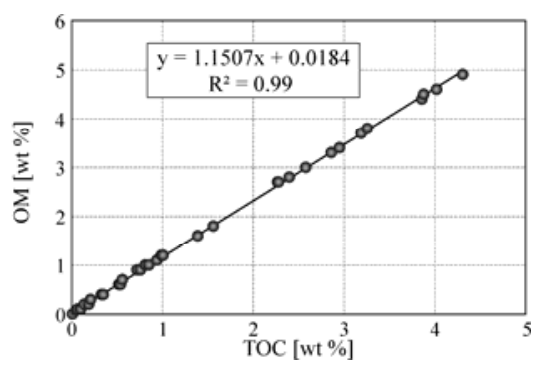

Fig. 2b. Relationship between organic matter content and Total Organic Carbon, Sa Formation

Simple linear relations were checked between all parameters in the study (Table 1) to check how big part of regression they explain. All of them were included in multiple regression to construct shale gas rocks model based on porosity and density as values determined continuously along the borehole axis in well logging. Parameters used as inputs into multiple regression were selected by interpreters on the basis of simple regression because of a limited number of cases in which there were complete data set with all quantities.

\subsection{Multidimensional regression}

Multidimensional regression was tested between density, porosity, TOC, and other available parameters. An exemplary result of bulk density (MIP) prediction on the basis of selected parameters (Table 3) for Ja Member is presented as equation (1):

$$
\begin{aligned}
\rho b= & 2.7898-0.19 \Phi_{\mathrm{DLP}}-0.05 \mathrm{CBW}+0.26 \Phi_{\mathrm{NMR}_{-}}+ \\
& -0.17 \mathrm{~S}_{\mathrm{w}, \text { irr }}-0.83 \mathrm{TOC}-0.05 \mathrm{~V}_{\mathrm{i}+\mathrm{s}}-0.07 \mathrm{~V}_{\mathrm{chl}}
\end{aligned}
$$

Symbols in equation (1) and Table 3 are the same as in Table 2 and subchapter 2.2. CBWmeans clay bound water [\%], $\mathrm{V}_{\mathrm{i}+\mathrm{s}}, \mathrm{V}_{\text {chl }}$ - volumes of illite + smectite and chlorite [\%] from XRD mineral analysis. Correlation coefficients between independent and dependent variables are included in Table 3. They illustrate the strength of relationship and contribution in evaluation which quantities are important in prediction. The correlation coefficient for multidimensional regression (eq. 1) is equal to $R=0.91$, determination coefficient $R^{2}$ is equal to 0.83 and corrected $\mathrm{R}^{2}=0.59$. 
Similar equation (2) was obtained for effective porosity (MIP) predicted on the basis of known parameters in Sa formation:

$$
\begin{aligned}
& \text { Фeff }=27.99-0.42 \Phi_{\mathrm{DLP}}+1.02 \mathrm{GD}_{\mathrm{WIP}}+0.49 \mathrm{CBW}+0.50 \mathrm{~S}_{\mathrm{w}, \text { irr }}-9.32 \rho \mathrm{b}+9.50 \rho \mathrm{s}+ \\
& -6.60 \mathrm{TOC}-2.16 \mathrm{~S} 1+0.08 \mathrm{~S} 2-1.75 \rho \mathrm{He}+0.01 \mathrm{U}-0.43 \mathrm{Th}+0.18 \mathrm{VCL}+6.69 \mathrm{OM}
\end{aligned}
$$

In that case correlation coefficient in multidimensional regression is equal to $\mathrm{R}=0.96$, determination coefficient $R^{2}$ is equal to 0.93 and corrected $R^{2}=0.63$.

In Figure $3 \mathrm{a}, \mathrm{b}$ there are presented regressions for predicted bulk density ( $\mathrm{b} \_$pred) and effective porosity (Фeff_pred) vs. their measured values. High determination coefficients for bulk density and effective porosity correlations are equal to 0.99 and 0.93 , respectively. They confirmed the ability of petrophysical properties prediction on the basis of the determination of various quantities, but Table 3 showed that contribution of selected parameters to variability explanation is different.

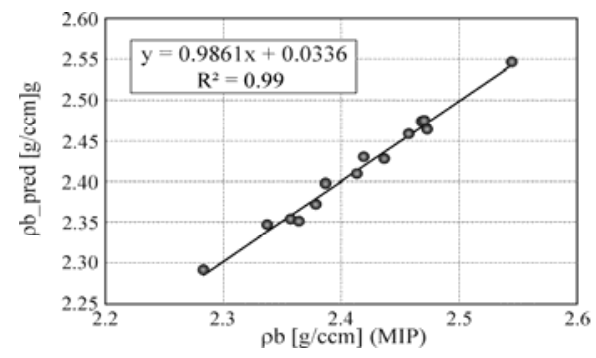

Fig. 3a. Relationship between predicted (eq. 1) and measured bulk density (MIP), Ja Member

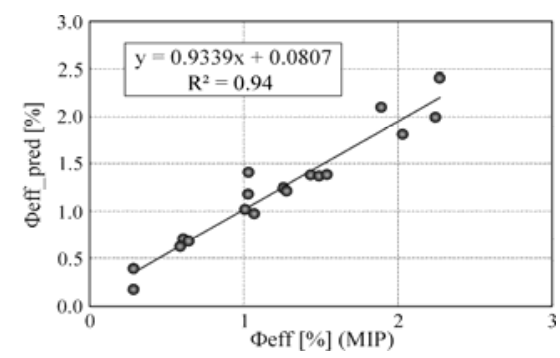

Fig. 3b. Relationship between predicted (eq. 2) and measured effective porosity (MIP), Sa Formation

\begin{tabular}{|c|c|c|c|c|c|c|c|c|c|c|c|c|}
\hline & $\Phi_{\text {WIP }}$ & $\Phi_{\text {DLP }}$ & $\mathbf{S}_{\mathrm{w}, \mathrm{irr}}$ & CBW & $\rho s$ & TOC & S2 & $\rho \mathrm{He}$ & $\mathbf{V}_{\mathrm{i}+\mathrm{s}}$ & $V_{\text {chl }}$ & OM & $\rho \mathbf{b}$ \\
\hline$\Phi_{\text {WIP }}$ & 1,00 & 0,96 & $-0,23$ & 0,61 & 0,49 & $-0,71$ & $-0,68$ & 0,69 & 0,27 & 0,39 & $-0,72$ & 0,40 \\
\hline$\Phi_{\text {DLP }}$ & 0,96 & 1,00 & $-0,19$ & 0,87 & 0,30 & $-0,69$ & $-0,71$ & 0,69 & 0,22 & $-0,08$ & $-0,97$ & 0,69 \\
\hline$S_{\mathrm{w}, \text { irr }}$ & $-0,23$ & $-0,19$ & 1,00 & $-0,23$ & $-0,34$ & 0,41 & 0,53 & $-0,11$ & 0,33 & $-0,17$ & 0,42 & $-0,26$ \\
\hline CBW & 0,61 & 0,87 & $-0,23$ & 1,00 & 0,77 & $-0,83$ & $-0,74$ & 0,65 & 0,07 & 0,19 & $-0,82$ & 0,04 \\
\hline$\rho s$ & 0,49 & 0,30 & $-0,34$ & 0,77 & 1,00 & $-0,81$ & $-0,69$ & 0,43 & 0,14 & 0,20 & $-0,81$ & 0,98 \\
\hline TOC & $-0,71$ & $-0,69$ & 0,41 & $-0,83$ & $-0,81$ & 1,00 & 0,96 & $-0,79$ & $-0,06$ & $-0,46$ & 1,00 & $-0,73$ \\
\hline $\mathrm{S} 2$ & $-0,68$ & $-0,71$ & 0,53 & $-0,74$ & $-0,69$ & 0,96 & 1,00 & $-0,82$ & 0,13 & $-0,48$ & 0,96 & $-0,60$ \\
\hline$\rho \mathrm{He}$ & 0,69 & 0,69 & $-0,11$ & 0,65 & 0,43 & $-0,79$ & $-0,82$ & 1,00 & 0,00 & 0,38 & $-0,78$ & 0,35 \\
\hline $\mathrm{V}_{\mathrm{i}+\mathrm{s}}$ & 0,27 & 0,22 & 0,33 & 0,07 & 0,14 & $-0,06$ & 0,13 & 0,00 & 1,00 & $-0,38$ & $-0,05$ & 0,13 \\
\hline $\mathrm{V}_{\text {chl }}$ & 0,39 & $-0,08$ & $-0,17$ & 0,19 & 0,20 & $-0,46$ & $-0,48$ & 0,38 & $-0,38$ & 1,00 & $-0,46$ & 0,13 \\
\hline $\mathrm{OM}$ & $-0,72$ & $-0,97$ & 0,42 & $-0,82$ & $-0,81$ & 1,00 & 0,96 & $-0,78$ & $-0,05$ & $-0,46$ & 1,00 & $-0,74$ \\
\hline$\rho b$ & 0,40 & 0,69 & $-0,26$ & 0,04 & 0,98 & $-0,73$ & $-0,60$ & 0,35 & 0,13 & 0,13 & $-0,74$ & 1,00 \\
\hline
\end{tabular}

Table 3. Correlations between independent variable, $\rho b$ and dependent variables, Ja Member

In bulk density case the most important role played skeleton density, organic matter content, TOC, grain density, and CEC (Tab. 3). Effective porosity calculated from the modified equation (2), without $\mathrm{S} 1, \mathrm{~S} 2$ and $\mathrm{OM}$, gave very similar result but parameters of correlation were as follows: $\mathrm{R}=0.95, \mathrm{R}^{2}=0.89$ and corrected $\mathrm{R}^{2}=0.70$. 
As a final result, the multidimensional regression was calculated to obtain relationships between bulk density and porosity from well logging and analyzed petrophysical parameters to build a statistical model of shale gas formation. Mutual connections between parameters measured in the laboratory and used as independent variables in the multidimensional regression, and quantities measured in well logging, showed the influence of selected variables on the output result. The regression equation for RHOB in the gas formation of Ja Member predicted on the basis of considered parameters is presented as equation (3):

$$
\mathrm{RHOB}=0.08-1.19 \mathrm{CBW}+1.57 \mathrm{GD}_{\mathrm{WIP}}+1.08 \rho \mathrm{b}-0.78 \rho \mathrm{s}-0.32 \mathrm{CEC}-0.10 \mathrm{~S}_{\text {wirr }}
$$

$\mathrm{R}$ equals to $0.95 \mathrm{R}^{2}=0.90$ and corrected $\mathrm{R}^{2}=0.82$. The most informative quantities, in that case, were clay bound water CBW and grain density from water immersed method GDWIP.

\subsection{Final confirmation of the built model}

Final confirmation of the constructed model quality was the comparison of the cumulated mass concentration of selected elements $(\mathrm{H}, \mathrm{Si}, \mathrm{Ca}, \mathrm{Fe}$ and $\mathrm{Al}$ ) calculated using Monte Carlo method for the spectral neutron-gamma device response with the results of GEM device measurements. Rock model was composed on the basis of highly correlated among themselves parameters which were checked in the simple and multidimensional regressions. In Figure 4 results of modelling of spectral neutron-gamma response are presented as mass concentration of selected elements as a function of the detector in $\mathrm{SN}-\mathrm{G}$ device position along the geological profile.

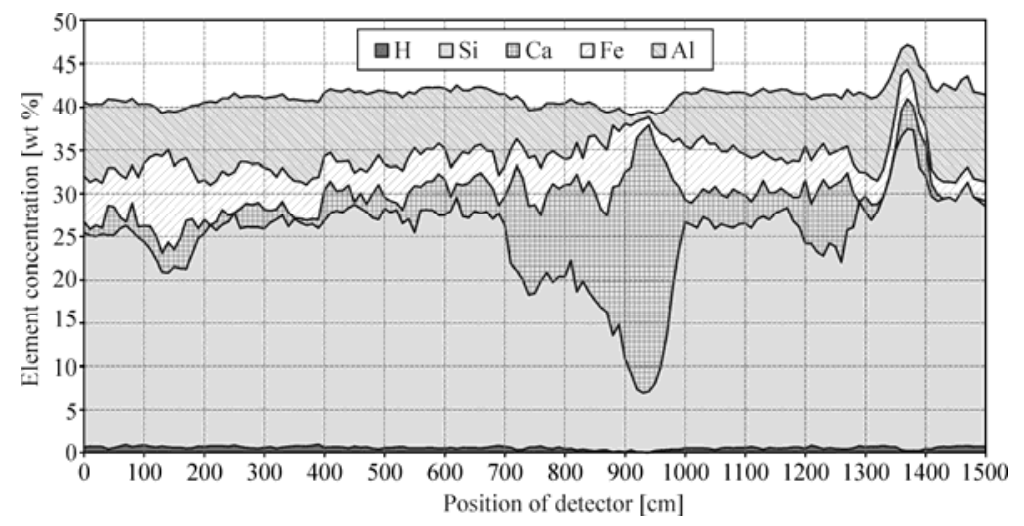

Fig. 4. The cumulated mass concentration of hydrogen, silicon, calcium, iron, and aluminum in the rock model calculated using Monte Carlo method for the spectral neutron-gamma device response

\section{Conclusions}

Variety of measured parameters allowed differentiation of the claystone/mudstone sweet spots among other Silurian and Ordovician formations of similar lithological characteristics. Simple statistics of measured petrophysical (reservoir and geochemical) properties and mineral composition provide good characteristics of sweet spots and can be treated as the primary indicators of the potential shale gas plays. Analysis of the results of simple linear regression showed mutual relations between properties and revealed important features of shale gas rocks. Cross-plots analysis enabled selection of the most informative parameters to model construction. Similar petrophysical parameters worked as the input data in the multidimensional regression for Ja Member and Sa Formation despite the difference in stratigraphy and 
heterogeneity of lithology. The most effective parameters providing characteristics of typical sweet spots in Polish shale gas plays consists of: porosity from different methods, bulk and skeletal density from MIP, grain density from WIP method, He pycnometer density, $\mathrm{S}_{\mathrm{w} \text {,irr }}$ from NMR experiment and mineral components: volume of illite, smectite and organic matter. Monte Carlo modeling worked effectively as confirmation of the modeled rock formation.

\section{Acknowledgements}

Data was allowed by POGC Warsaw co, Poland for the MWSSSG Polskie Technologie dla Gazu Łupkowego project (2013-2017). Authors thank prof. dr. Leszek Czepirski and his team for N vapors adsorption/desorption $(77 \mathrm{~K})$ measurements, dr. R. Semyrka for mercury injection porosimetry, prof. dr. A. Derkowski and T. Topór, M.Sc. for WIP porosimetry, D. Dworak, M.Sc. for Monte Carlo modeling and dr. T. Zorski for cooperation in defining problems.

\section{References}

1. H. Kiersnowski, in: Nawrocki J. (ed.), Shale gas as seen by Polish Geological Survey Polish Geological Institute - National Research Institute 26-31 (2013)

2. P. Poprawa, Przegląd Geologiczny (in Polish, Abstract in English), 58, 3226-249 (2010)

3. D. Więcław, M.J. Kotarba, P. Kosakowski, A. Kowalski, I. Grotek, Geological Quarterly, 54, 2, 159-182 (2010)

4. T. Topór, A. Derkowski, P. Ziemiański, L. Marynowski, D.K. McCarty, Int. Journal of Coal Geology, 179, 45-59, (2017) https://doi.org/10.1016/j.coal.2017.05.001

5. T. Topór, A. Derkowski, P. Ziemiański, J. Szczurowski, D.K. McCarty, Int. Journal of Coal Geology, 180, 46-56, (2017) https://doi.org/10.1016/j.coal.2017.07.005

6. U. Kuila, D.K. McCarty, A. Derkowski, T.B. Fischer, M. Prasad, Fuel, 117, 1115-1129 (2014)

7. T. Topór, A. Derkowski, K. Utpalendu, T.B. Fischer, D.K. McCarty, Fuel, 183, 537-549 (2016)

8. M. Thommes, K. Kaneko, A.V. Neimark, J.P. Olivier, F. Rodriguez-Reinoso, J. Rouquerol, K.S.W. Sing, Pure and Applied Chemistry, 87, 9-10, 1052-1069 (2015)

9. F. Rouquerol, J. Rouquerol, K.S. W. Sing, P. Llewellyn, G. Maurin, Adsorption by Powders and Porous Solids: Principles, Methodology and Applications (Academic Press, 2014)

10. M.J. Kotarba, M. Lewan, D. Wieclaw, Shale gas and oil potential of Lower Palaeozoic strata in the Polish Baltic Basin by Hydrous Pyrolysis. Fourth EAGE Shale Workshop. Shales: What do they have in common? 6-9 April, Porto, Portugal, (2014)

11. K. Wawrzyniak-Guz, J.A. Jarzyna, M. Zych, M. Bała, P.I. Krakowska, E. Puskarczyk,Analysis of the heterogeneity of the Polish shale gas formations by Factor Analysis on the basis of well logs. In: Extended abstracts of the 78th EAGE Conference and Exhibition, 30 May - 2 JuneVienna, 2016, Tu SBT3 07, (2016)

12. J.A. Jarzyna, M. Bała, P.I. Krakowska, E. Puskarczyk, A. Strzępowicz, K. WawrzyniakGuz, D. Więcław, J. Ziętek M. Shale Gas in Poland, in: Advances in Natural Gas

Emerging Technologies, DOI: 10.5772/67301 (2017)

http://www.intechopen.com/articles/show/title/shale-gas-in-poland 